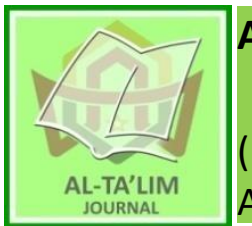

AL-TA'LIM JOURNAL, 25 (3), 2018, (224-233)

(Print ISSN 1410-7546 Online ISSN 2355-7893)

Available online at http://journal.tarbiyahiainib.ac.id/index.php/attalim

\title{
Street Children Religious Education: A Study on Car Window Cleaning Kids in Jambi
}

Received: $07^{\text {th }}$ July 2018; Revised: $04^{\text {th }}$ September 2018; Accepted: $26^{\text {th }}$ November 2018

Permalink/DOI: http://dx.doi.org/10.15548/jt.v25i3.510

\section{As'ad Isma*)}

Universitas Islam Negeri Sulthan Thaha Saifuddin , Jambi Indonesia E-Mail: asadisma@uinjambi.ac.id

\section{Muhammad Junaidi HB}

Universitas Islam Negeri Sulthan Thaha Saifuddin , Jambi Indonesia E-Mail: junaidi@gmail.com

*) Corresponding Author

\begin{abstract}
Children begin careers on the streets in several locations in the city of Jambi. They work on the streets as street musicians, vehicle glass cleaners, newspaper and tissue sellers, both forcibly and deliberately. Their existence is influenced by some factors, such as family neglect and socio-economic conditions; as well as finding work on the streets and sustaining the work are much easier than looking for work which uses energy or mind. The purpose of this research is to study the religious education of street children who become car glass cleaners which has increased significantly compared to other street professions. This study aims to explore two issues: where the children obtain their religious education and to what extent they practice it in their daily life. Qualitative collecting data techniques were used including observation and interviews. This research found that the street children interviewed in this study only had access to religious educatsion at morning school. They do not attend madrasah, the Qur'an educational school or Taman Pengajian Alquran (TPA), and Sekolah Islam Terpadu. The dominant factors affecting their religious education were their school and their peer group at school. Meanwhile, parents seldom practice the religious duty in family, thus the parents' influence on the children's religious practices was minimal. Therefore, this research recommends other actors give early religious education for street children. Religious education can be integrated with their shelter homes which can be their early Islamic religious education.
\end{abstract}

Keywords: Street children; religious education; car window cleaning kids

How to cite: Isma, A., \& Junaidi HB, M. (2018). Street children religious education: a study on car window cleaning kids in Jambi. Al-Ta Lim Journal, 25(3). doi:http://dx.doi.org/10.15548/jt.v25i3.510

\section{INTRODUCTION}

Street children, as stated by (Beazley, 2003b, 2003a; Ennew \& Swart-Kruger, 2003) often experience negative stigma as criminals, drug addicts, anti-social and juvenile delinquents. On the other hand, their existence is also sometimes considered as children who need more attention for being victims of families, adults and unable to protect themselves on street (Glauser, 2015; Panter-Brick, 2002; Thomas de Benítez, 2007). In the discourse of stigma and drama, the education and ethics promoted by religious education will be explored in this paper.

The discourse on street children can also be viewed from various perspectives in social science theory, both from the point of structuralism theory, in which the existence of street children is the result of dominant structures that have hegemonic power over other social entities resulting in marginalization; and can be viewed as part of the field of symbolic interactions theory in 
which humans become actors for their daily actions or interactions. Functionalism also contributes to the analysis of street children as without a social equilibrium, social functions are hampered which gives rise to dominant and marginalized groups, but the dominant and marginalized groups will soon disappear because of the power of social equilibrium (Beazley, 2000; Young \& Barrett, 2001). In these social theories, the State holds power, structure and is the enduring system for social organization.

This perspective relies on the concept of social balance and that the presence of street children, including in Jambi, is due to the disappearance of social balance. The main argument of the discussion is the absence of the State in dealing with street children in the Indonesian context. The $5^{\text {th }}$ principle of Pancasila and the constitution article 34 verse 1 states that abandoned children should be nurtured by the state.

According to the argument in this paper, the state would not always be a determinant of official action toward the existence of street children, which reflects the perspective of the majority of citizens toward street children. In this era of information technology, the state can move the supporting media elements to draw public discourse. The dominant perspective created by government that draws public discourse need to be responded by civil society (Ali, Shahab, Ushijima, \& de Muynck, 2004; Beazley, 2015; West, 2003). However, the state discourse could become a regulation which influences the regional government in terms of understanding, thought and policy, because it is an obligation to follow the central government in managing street children issues.

The positive impact of the State government's and their regulation is that it raises the local governments' perspective, like encouraging city and district governments to make their cities a city of worthy children. This discourse was highlighted when Indonesia ratified the International Convention on the Rights of the Child and has issued Law No. 23 of 2002 on Child Protection. Kota Layak Anak (KLA) or Child Friendly City is a city in which children are assured of their social, cultural and economic life. Since 2008, the Ministry of Women and Children's Empowerment has been pushing this Child Friendly City or KLA policy, including efforts to overcome the existence of children on the streets who are considered to be not living the childhood they should have (Dewi, 2011; Hamudy, 2015; Irmawati, 2010; Prasetyo, 2013; Rumtianing, 2016; Saputri, Rostyaningsih, \& Maesaroh, 2014; Subiyakto, 2012).

It is also important to note that before the KLA policy was created, the categorization of street children existed into two categories: pure street children and street children. Pure street children they live in the street, free to remote anywhere and work from morning, while street children they still have family and house, and work part time in the street (Astri, 2014; Nurwijayanti, 2012) ; or three categories as Ampel (2008) stated, children working on the street, children living on the street, or children who are likely to become street children. This categorization appears as it is related to the children with minimal education who receive less attention from the state. In fact, the message is also often conveyed by this categorization that street children education is urgent, including religious education. The initiatives concerning the importance of education, religious education, and other social need for marginalized society groups are often emerging from the community, from the public, not from the government and its regulations. Shelter houses are made from an agreement and gotong royong or self-help community members or a particular community (Hidayati, 2012; Moeliono, 2004; Rizzana, 2013; Rohman \& Rohman, 2009; Sari, 2015; Setijaningrum, 2008).

The awareness of education and religion at a young age has become important to people from the Indonesian archipelago who view it as a key element in forming the character and ethics of eastern civilization. 
The process of growing children has also become a concern, particularly to lead and guide the next generation to the goals of this country. However, for the current context of Jambi, a small percentage of children are still on the streets. There has been minimal attention from the government and the community to those who are currently still struggling on the streets to overcome their economic and family problems. The affection of the parents, in some cases, if any, is gained while doing the street economic activity.

This article discusses the social conditions especially in term of religious education of children who work as glass vehicle cleaners on the streets and conveys the facts of street children's existence in several locations in Jambi. The main concern of this research is to understand the children's religious knowledge, where the children obtain their religious education, and to what the extent they practice it in their everyday life.

\section{METHOD}

The qualitative research underlying this article was conducted in December 2017 and June 2018 by conducting observations and open ended recorded interviews with nine street children located in three different locations: Bank Indonesia traffic light, Simpang Bata Pasar traffic light and Simpang Masjid Agung traffic light in Jambi. The site selection and the number of informants from glass car cleaner kids were based on the fluctuating existence of street children themselves. Those three areas are frequently used by working street children, although the number of children present varies day to day. The interview was repeated toward three of street children informant to gain more data. The two other interviewees for this study were a social activist and a civil servant for social welfare in the district office of Jambi. Each interviews conducted in one to two hour and through preparation meeting before to reassure the informants telling stories as they are. For the ethical purpose the informant only mentioned by initial.

\section{RESULT AND DISCUSSION}

\author{
Car Window Cleaning Kids at Jambi Traffic \\ Lights
}

The number of street children continues to increase as their total number in Jambi continues to grow from year to year. Although there are no detailed figures, the change of crowds in some street children locations indicates the population of working children increase in number. Based on interviews and the empirical studies, the main factor of children pursuing careers in becoming window car cleaners is mainly due to economic factors. They were in school age, between 9 to 15 years old. Smaller children choose other street jobs such as selling newspapers and tissues, while the teens were cleaning car windows or singing. Their families are at the level of poor families, which is in line with the number of poverty in Jambi based on Central Bureau of Statistics (BPS) of Jambi data 2010.

Data from the Central Bureau of Statistics (BPS) of Jambi states that $47.11 \%$ of the city was classified as urban poor in June 2010 (from a total population of 446,872 people) (BPS, 2012). The number of urban poor has increased due to urbanization and migration. The presence of new residents fills the existing tenements in many places in the city of Jambi. Migration from South Sumatra was an important trigger for the rapid increase of population in Jambi and also the poverty rate. Field observations in the Kasang area which is the nearest to the Angso Duo Market, for example, found that people had migrated from South Sumatra following the social network of their families who have already come to Jambi or following work provided by relatives and acquaintances who first pioneered careers in Jambi. According to informants, family economic factors are the main factors that encourage these migrant children to work on the streets.

Economic factors are the triggers for the 'creativity' of works on the streets. However, it is important to note that the lack 
of Government support is likely to affect the number of children working on the streets. One of the child participants of this study admitted that his family income is minimal, and he has been working selling newspapers on the street since the third grade of elementary school. He trades on the street after finishes school, from 2 to $5 \mathrm{pm}$ to help the family economy (interview $\mathrm{Kdr}$ on $3^{\text {rd }}$ December 2017). Two other street children, $\mathrm{AS}$ and FEB (interview on $2^{\text {nd }}$ December 2017), admitted besides trading on the street they also often do begging to help the cost of school and to help their parents, although the money obtained was not much, around ten until twenty thousands (interview Feb on $1^{\text {st }}$ December 2017).

These three participants explained that they did their activities at the traffic light intersection because of their own willingness to help their family economy. They said that they met on the streets without agreement or negotiation, and divided space to make money on the street in a negotiation manner. They said that the revenue earned is kept for their own benefit.

Yenti, Huda, \& Piadi (2008) argues that street children who work on the orders of their parents and their own volition may be expressing a 'love' relationship that may be considered exploitation to others. Parents do not want their children to be hungry because they cannot afford to feed them while they are unable to get a good job, on the other hand they do not earn much money if they themselves are on the streets, because the sympathy of the street users to them is lower than the children. Therefore, they choose other work such scavenging or laboring while their children work in the street.

Some street children at traffic lights in Jambi also consider themselves to be doing positive activities that have a positive impact on their families. $\mathrm{Hr}$, an informant who was interviewed on $4^{\text {th }}$ December 2017, stated that he has been trading at a traffic light since the first year of primary school and the money he earned was for saving, "after school I sell newspapers, and I get thirty thousand from selling daily newspapers at traffic light Simpang Empat Telanaipura. I saved and take the money out only in urgent situation or needed by my family". This indicates that the parents also use the money their children earned which means that their children are utilized by their parents as manpower and income resource. However, how the parents and children interact, and their relationship, will determine the utilization of such income. The love, as Zarfina stated above, is perhaps the key concept of parents-children interaction.

The pattern of interaction among street children is warm but individualist or selfish. The income one gains in the same job sector is rarely shared with their friends. Earnings are only for individual, unless they work in group and in incidental work, like the groups of punk children do; they sing and collect money together, in order to have food collectively. Selfishness among street children could be caused by economic difficult situation, "being here, singing, on your own from afternoon to night on school days, the money we get each is in our own" (interview Imel on $9^{\text {th }}$ December 2017), and this situation is likely to cause other negative attitudes.

From the observations, there are street children who often use harsh words. A road user interviewed for this research complained that when a street child was cleaning his vehicle glass, he spoke a harsh word for not being given money by him (interview a driver Sprd on $4^{\text {th }}$ December 2017). This attitude if it is referred to the attitude of the indigenous Jambi Malay is contradictory. However, contact with other groups on the street does allow socialization of behavior or behavioral reciprocity to occur. More interestingly, according to an informant, Strm. one of the members of the Civil Service Police Unit or Satuan Polisi Pamong Praja of Jambi, street children in Jambi are also the punk children who are not originally from Jambi:

Based on data collected by Civil Service Police Unit (Satpol PP) Jambi, most of these street children are not residents of 
Jambi. Among them there are residents from Lampung, Jakarta and even Denpasar, Bali (who came to Jambi). Some street children who were interviewed admitted to come to Jambi to seek experience.

This information is confirmed by one of the street children interviewed, Ihsan who stated that he came from Bandung and moved in groups with his friends because he chose to live freely. Street children have become phenomena that demand much attention. Psychologically they are children who at some stages require the psychological foundations of a family that form a strong emotional mentality, while at the same time they have to wrestle with a hard world of the street which tends to negatively affect the development and formation of their personality (Woolfolk, 2007). According to Rt, an officer in Social Security Office (interview $13^{\text {th }} \quad$ December 2017), this psychological aspect has a strong impact on the social aspect, where their emotional and mental as well as the appearance of the slums, gives negative impressions on street children who are often identified as troublemakers, slum children, thieves who must be removed from society.

\section{Motivation in Street Career}

A study conducted by UNICEF on adolescents categorized by street adolescents shows that their motivation to live on the streets is not merely because of the pressing needs of the household economy, but also because of the violence and rift of their parents' household life. For these street children, although life on the streets is no less violent it is considered a safer alternative to living in a family full of violence that they cannot avoid. Although it is not always the case, it is often found that the background of children choosing to live on the streets is due to cases of inappropriate treatment (Bagong \& Hariadi, 2002).

In Jambi, the motivation of street children to choose to trade, work and have careers on the streets is 'reward' or 'compensation' and comfort. In the dictionary of Psychology, compensation is part of the subject's expression of anger and self-defense mechanisms in which an individual substitutes an activity with other activities to satisfy his/her failures. These are structural and cultural failures of the family which cause children to engage in other activities as an expression of disappointment over the situation, and in return for this failure to make other existing or non-existent efforts (Invernizzi, 2003).

In the context of comfort O'Connor (2002) who has observed the lives of street children, also states that the comfort factor causes the children to feel at home in the street. The feeling of comfort felt by street children in Jambi finally makes them enjoy their existence more with other peers, with the attributes and symbols shown. Their identity is being formed. Their mindset is also carried in the world of street children. They feel that street children are the right choice for them (De Moura, 2002; Dybicz, 2005). An informant even stated that being at home makes him more uncomfortable than being with friends on the street. The way he thinks, being on the street is a vehicle of unregulated freedom (interview Rjk $4^{\text {th }}$ December 2017). Jmlh (interview $6^{\text {th }}$ December 2017), an informant from social activists also stated that the young generation who are members of the street children community see their concept and thoughts as part of their unique and distinctive style, although it is actually influenced by foreign culture.

Fashion styles for example, which are worn by punk teenagers include boots, Mohawk haircuts, Feather cut and colored with bright colors. Chains, spikes, leather jackets, tight jeans and shabby clothes, symbolize that they are anti-establishment, anti social, they really want to be viewed as being from the low class. The identity being sought by these street children requires both official state education and informal education built by the community. 


\section{Religious Education among Street Children}

At the beginning of this paper, the statement was made that street children are the responsibility of the state as mentioned in the 1945 Constitution article 34 verse 1. Unfortunately, all the informants admitted that they never received an invitation to attend other formal education, including religious education from the local government or other state institution. The Ministry of Religious Affairs and the Ministry of Education appear not to treat them as Indonesian children who may potentially influence the history of the Indonesian nation in the future.

Although madrasah or Islamic religious schools are still around the street children's houses, the street career prevents them from attending this Islamic school. The most likely Islamic informal school is a short ta'lim after sunset praying (pengajian bakda magrib), at night when they are already at home. The lack of religious education they experience causes them to feel that they are not the same as other children of the same age, hence the negative self-concept happens or they view themselves as inferior (Kumalasari \& Wijayanti, 2013; Pamuchtia \& Pandjaitan, 2010; Pardede, 2011).

However, it is immediately important to note that the real role of the family is equally important. According to Gilbert, Baldwin, Irons, Baccus, \& Palmer (2006), parents are the earliest and most powerful social contact. As a result, parents become very important for children. What parents communicate to their children is more embedded than any other information the children will receive in their life. Regardless of the parental treatment of children, the children suspect that they deserve to be treated as such.

Families should be the lead that provides, educates, directs, and most importantly the family should be designed as a comfortable place for children to discuss issues of interest to the child. For example, when children see scenes of street children on
$\mathrm{TV}$, then parents may directly describe the negative effects of street life, so that children will not be affected to join the street children (Interview Rmt, an officer from Social Welfare Security Office). Character and religious education should start from the smallest social unit, a family.

The majority of informants of this study claimed that their families do not educate them maximally about religious matters. Islamic education is considered not an important thing. In fact, they said that their parents do not do praying or fasting. Therefore, religious knowledge is derived only from the schools they attend from morning to afternoon. They do not attend the madrasah and the Qur'an Recitation School. Iqro' is only studied during the morning school. The willingness to study Qur'an among the street children was still high, but limited by the absence of religious teachers and places after morning school. They conveyed the will to the researchers and hope there is religious education provided free of charge to them.

On the other hand, the public also handed over religious education and character to the Government. In the social life of urban Malay Jambi, the commercialization of religious education takes place in the public sector itself. Anxiety about the social influence that exists and threatens children of middle-class group has been exploited to raise the cost of religious education. As a result, religious education carried out by the community becomes more expensive. Integrated Islamic Primary School (SDIT) in the modern Jambi with a good curriculum, professional teachers and good teaching and learning media is unattainable for street children. SDIT belong to middle-class and elite workers who have a steady income and expect their children to be the bright generation. This primary school is not an option for the street children's religious education. The only hope of community religious education is a madrasah kampung or Village Islamic School founded by community religious leaders who do not 
expect profane rewards. This possibility still exists because the religious schools used to be called Sekolah Arab or Sekolah Madrasah were formerly carried out continuously with public elementary school education in the morning. Some madrasah use public schools classes. The tuition fee of madrasah depends on the ability of each child's parents. However, as capitalism and modern life grew steadily, the village madrasah is drastically reduced. Fortunately however, the Ministry of Religion Affairs seems to still have concern for the madrasah by providing assistance to community religious leaders who opened and managed this community madrasah.

The revitalization of madrasah schools in Jambi society is not difficult because this community-based religious education is part of the process of Islamization or embedded in Malay tradition for many years. Roff (2009) incorporated the Sekolah Arab as part of the Islamization of the Malay Peninsula since 1890-1990 which also had a major influence in the Islamization of Malay people in Sumatra. The opportunities to provide religious education through this Sekolah Arab or Madrasah Kampung for the street children for free is still widely opened as an alternative to nongovernment religious education which is increasingly more and more expensive.

Traditional Islamic education through madrasah has been ongoing since the beginning of the 20th century across the city of Jambi or Seberang Kota Jambi. This place has become the center of Islamic education for agrarian children from upstream to downstream in Jambi (Kusnadi, Sobur, \& Aziz, 2017). Islamic teachers teaching in these schools are students of the early generation of Jambi religious leaders. The Tuan Guru, or oldest teachers, learned Islamic education directly in Mecca. They returned home to Jambi and established madrasah with a traditional education system called madrasah salaf, and then passed the model on to the next generation of religious teachers, both serving in their madrasah or setting up their new madrasah. The shifting role of religious leader or Tuan Guru does occur due to the construction of Batanghari 1 Bridge infrastructure to Seberang Kota Jambi, but the inheritance of the Tuan Guru, the traditional madrasah still exists even in the heart of the Jambi (Isma, 2005). This heritage is treated as part of an education safeguard for the Jambi Malay generation yet it declined during the crisis and inflation in 1998.

The degradation of local community madrasah, perhaps causes several community members and students who were interviewed for this research to expect the government to conduct regular raids to reduce the presence of street children and immediately rehabilitate them and provide proper religious education. In fact, some suggest expanding the role of social institutions to become a vehicle for street children education, including religious education and skills.

The majority of the research informants considered that although the career on the streets helped them economically, it was temporary. The reality of the streets is that it is not a good place for school-age children and teenagers. Negative influences such as drugs and criminality can easily thrive on the streets, due to the lack of community social control. Humans have the urge to violate in certain situations, but it can be controlled by an environment that usually makes individuals refrain from violent impulses.

\section{CONCLUSSION AND RECOMMENDATION}

Street children are school-aged children like other children. They deserve religious attention and education. This study has shown that religious education among car windows cleaning kids is minimal and yet they hope to receive the same religious education as other children. They expect religious education from institutions outside the family. The parents of several informants in this study indicate that the role model for the implementation of religious rules is not a concern among parents. Therefore, top down 
and bottom up initiatives, both religious education derived from government initiatives, as well as from the community's own initiatives such as Pengajian Bakda Magrib, Sekolah Arab or Madrasah Kampung is essential to maintain equitable balance and social equity of education for all children and for the future of Indonesian religion and state.

\section{REFERENCES}

Ali, M., Shahab, S., Ushijima, H., \& de Muynck, A. (2004). Street children in Pakistan: A situational analysis of social conditions and nutritional status. Social Science \& Medicine, 59(8), 1707-1717.

Ampel, K. S.-S. (2008). 5 Efektivitas Kebijakan Perlindungan Pekerja Anak (Child Labour) Dengan Fokus Anak Jalanan Di Surabaya.

Astri, H. (2014). Kehidupan Anak Jalanan Di Indonesia: Faktor Penyebab, Tatanan Hidup dan Kerentanan Berperilaku Menyimpang. Jurnal Aspirasi, 5(2), 145-155.

Bagong, S., \& Hariadi, S. S. (2002). Krisis dan Child Abuse, Kajian Sosiologis tentang kasus Pelanggaran Hak Anak dan Anak-Anak yang membutuhkan Perlindungan Khusus (Child in Need of Special Protection). Surabaya: Airlangga Univercity Press.

Beazley, H. (2000). Street boys in Yogyakarta: social and spatial exclusion in the public spaces of the city. A Companion to the City, 472488.

Beazley, H. (2003a). The construction and protection of individual and collective identities by street children and youth in Indonesia. Children Youth and Environments, 13(1), 105-133.

Beazley, H. (2003b). Voices from the margins: Street children's subcultures in Indonesia. Children's Geographies, 1(2), 181-200.

Beazley, H. (2015). Multiple identities, multiple realities: Children who migrate independently for work in Southeast Asia. Children's Geographies, 13(3), 296-309.

De Moura, S. L. (2002). The social construction of street children: Configuration and implications. British Journal of Social Work, 32(3), 353-367.

Dewi, S. M. (2011). Transformasi Kudus sebagai Kota Layak Anak: Tinjauan atas Pemenuhan Hak Sipil dan Partisipasi. Muwazah, 3(1), 398-410.

Dybicz, P. (2005). Interventions for street children: An analysis of current best practices. International Social Work, 48(6), 763-771.

Ennew, J., \& Swart-Kruger, J. (2003). Introduction: Homes, places and spaces in the construction of street children and street youth. Children Youth and Environments, 13(1), 81104.

Gilbert, P., Baldwin, M. W., Irons, C., Baccus, J. R., \& Palmer, M. (2006). Self-criticism and self-warmth: An imagery study exploring their relation to depression. Journal of Cognitive Psychotherapy, 20(2), 183-200.

Glauser, B. (2015). Street children: deconstructing a construct. In Constructing and reconstructing childhood (pp. 146-162). Routledge.

Hamudy, M. I. A. (2015). Upaya Mewujudkan Kota Layak Anak di Surakarta dan Makassar. Jurnal Bina Praja: Journal of Home Affairs Governance, 7(2), 149-160.

Hidayati, D. (2012). Aktivitas Waktu Luang (Leisure) Anak Jalanan Di Sekitar Simpang Lima Kota Semarang (Studi 
Anak Jalanan Binaan Yayasan Setara). Journal of Nonformal Education and Community Empowerment, 1(2).

Invernizzi, A. (2003). Street-working children and adolescents in Lima: Work as an agent of socialization. Childhood, 10(3), 319-341.

Irmawati, N. (2010). Responsivitas Pemerintah Kota Surakarta Terhadap Perlindungan Anak Menuju Solo Kota Layak Anak (KLA) (PhD Thesis). Universitas Sebelas Maret.

Isma, A. (2005). Pergeseran Peran Sosial Tuan Guru dalam Masyarakat Jambi Seberang. Kontekstualita; Jurnal Penelitian Sosial Keagamaan, 20(1).

Kumalasari, P. P. W., \& Wijayanti, D. Y. (2013). Konsep diri anak jalanan usia remaja di wilayah Semarang Tengah. Jurnal Keperawatan Jiwa, 1(2).

Kusnadi, E., Sobur, K., \& Aziz, A. (2017). In Between Islamic Boarding School: a Study of Al-mubarok Al-islam Within the Social Changes of Seberang Kota Jambi. Addin, 11(1), 101-130.

Moeliono, L. (2004). Pendampingan anak jalanan menurut para pendamping anak jalanan: laporan dari" Annual Retreat" 2003 pendamping anak jalanan Proyek Urban Street Children Empowerment and Support (USCES), Save the Children-US. Pusat Kajian Pembangunan Masyarakat, Unika Atma Jaya.

Nurwijayanti, A. M. (2012). Eksploitasi anak: Perlindungan hukum anak jalanan dalam perspektif hukum pidana di Daerah Yogyakarta (PhD Thesis). Universitas Muhammadiyah Surakarta.

O'Connor, A. (2002). Local scenes and dangerous crossroads: punk and theories of cultural hybridity. Popular Music, 21(2), 225-236.
Pamuchtia, Y., \& Pandjaitan, N. K. (2010). Konsep Diri Anak Jalanan: Kasus Anak Jalanan di Kota Bogor Provinsi Jawa Barat. Sodality: Jurnal Sosiologi Pedesaan, 4(2).

Panter-Brick, C. (2002). Street children, human rights, and public health: A critique and future directions. Annual Review of Anthropology, 31(1), 147171.

Pardede, Y. O. K. (2011). Konsep diri anak jalanan usia remaja. Jurnal Ilmiah Psikologi, 1(2).

Prasetyo, M. I. (2013). Evaluasi Kebijakan Sidoarjo Kota Ramah Anak di Kecamatan Krembung, Kabupaten Sidoarjo. Universitas Airlangga. Jurnal Skripsi Tidak Diterbitkan.

Rizzana, S. (2013). Analisis kebijakan perlindungan anak jalanan dalam rangka pengentasan dari segala bentuk eksploitasi (studi pada dinas sosial Kota Malang dan lembaga pemberdayaan anak jalanan griya baca). Jurnal Administrasi Publik, 1(3), 174-182.

Roff, W. R. (2009). Studies on Islam and society in Southeast Asia. Singapore University Press.

Rohman, A., \& Rohman, A. (2009). Fenomena Anak Punk: Sisi Lain Mengenai Ruwetnya Permasalahan Anak Jalanan di Indonesia. Warta Demografi.

Rumtianing, I. (2016). Kota Layak Anak dalam Perspektif Perlindungan Anak. Jurnal Ilmiah Pendidikan Pancasila Dan Kewarganegaraan, 27(1).

Saputri, V. R. D., Rostyaningsih, D., \& Maesaroh, M. (2014). Analisis Perencanaan Kota Layak Anak di Kota Semarang. Journal of Public Policy and Management Review, 3(3), 182-191. 
Sari, R. F. S. (2015). Studi Deskriptif tentang Efektivitas Pemberdayaan dalam Meningkatkan Kemandirian Anak Jalanan di Unit Pelaksana Teknis Dinas (UPTD) Kampung Anak Negeri Dinas Sosial Kota Surabaya. Jurnal Kebijakan Dan Manajemen Publik, 3(1).

Setijaningrum, E. (2008). Analisis kebijakan pemkot surabaya dalam menangani anak jalanan. Jurnal Penelitian Dinamika Sosial, 7, 16-22.

Subiyakto, R. (2012). Membangun kota layak anak: Studi kebijakan publik di era otonomi daerah. Sosio Religia, 10(1), 49-71.
Thomas de Benítez, S. (2007). State of the world's street children: Violence.

West, A. (2003). At the margins: street children in Asia and the Pacific.

Woolfolk, A. (2007). Education psychology. Boston: Pearson Edition.

Yenti, Z., Huda, S., \& Piadi, A. (2008). Anak Jalanan di Simpang Lampu Merah Telanaipura Kota Jambi (Analisis Terhadap Dampak Eksploitasi Anak). Kontekstualita: Jurnal Penelitian Sosial Keagamaan, 23(2).

Young, L., \& Barrett, H. (2001). Adapting visual methods: action research with Kampala street children. Area, 33(2), 141-152. 